\title{
IL12RB2 wt Allele
}

National Cancer Institute

\section{Source}

National Cancer Institute. IL12RB2 wt Allele. NCI Thesaurus. Code C52045.

Human IL12RB2 wild-type allele is located within 1p31.3-p31.2 and is approximately $90 \mathrm{~kb}$ in length. This allele, which encodes interleukin- 12 receptor beta- 2 chain protein, plays a role in the proliferation of both T cells and natural killer cells. It is also involved in Th1 cell differentiation. Up-regulation of the IL12RB2 gene is associated with certain infectious diseases such as Crohn's disease and leprosy. 